\title{
Diagnosing Adoption to Mobile Learning
}

\author{
https://doi.org/10.3991/ijim.v13i08.10083
}

\author{
Eliza B. Ayo ${ }^{(凶)}$, Marcial L. Anacio, Lani E. Sakay, \\ Rosemarievic A. Bustamante, Teresita S. Mijares \\ Centro Escolar University, Manila, Philippines \\ ebayo@ceu.edu.ph
}

\begin{abstract}
This study was undertaken to address the need to modernize the modes of teaching and learning pedagogy by taking advantage of the proliferation of electronic gadgets and mobile devices since, as counted there are more computers than the people in the world [1]. This research found out how learning in the new platform could be adopted by teachers and students. In addition, it tested the different variables involved in the use of mobile in learning by faculty and students of Centro Escolar University (CEU) to determine factors that made implementing technology a success or a failure.

To attain the set objectives, this study made use of descriptive and inferential method to the data gathered from respondents via stratified random sampling. Specifically, it employed frequency, mean, standard deviation, t-test, analysis of variance and multiple linear regressions for the treatment of data derived from the survey questionnaires. To complete the triangulation approach and for consistency of findings, observation and interview were also conducted.

Subsequently, in order to determine adoption to mobile learning the modified Unified Theory of Acceptance and Use of Technology (UTAUT) model was employed. This model shows relationship of moderating variables which are age, gender, voluntariness of use and experience from independent variables like performance expectancy, effort expectancy, social influence, facilitating conditions, anxiety and self-efficacy.

After all the statistical treatments were applied, Anxiety, Self-Efficacy, Effort Expectancy, Performance Expectancy and Facilitating Condition contribute to the success of the introduction of technology to the organization, while social influence was excluded as the reasons why users adopt it.
\end{abstract}

Keywords-Mobile learning, technology adoption,

\section{Introduction}

A new breed of era started when mobile devices landed on peoples' hands. These technology savvy individuals find ways on how to use these gadget to their advantage. With the recent studies [2], [3] it revealed that by 2020 the number of things connected to the internet will reach 50 billion and by the year 2019 there are 5 billion smart phone and tablet users. 
Looking at the spread of these gadgets, this will make an impact in all fields. From industrial to manufacturing to agriculture, this phenomenon could be an enabler to more advanced things or could disrupt existing traditions and processes. Education will not be spared from it. In fact Daniel Burrus, chief executive officer of Burrus Research Associates Inc., predicted that mobile learning represents an amazing disruption and opportunity [4].

The use of innovative technology in the classroom has a positive impact on students learning [5]. As a way of embracing changes, it is interesting to note that schools and universities are coping up by searching and introducing new platforms. They are working towards improvement and innovation, knowing that classroombased lessons and other approaches may not suffice to the growing mobile users and fast paced development in technology. The availability of these gadgets combined with creativity of teachers, this tool can be used to deliver quality teaching and amazing learning experiences among students.

However, implementing mobile learning is still not as easy as $a b c$, aside from learning the technicality to use this state the of the art technology, human factors in order to adopt it, needs to be studied as well. What are the factors that will make teachers and students adopt mobile learning? If there are studies that show people reject new technologies when they replace humanity while embraces them when they support human desire for purpose, challenge, meaning and alignment with nature even if these technologies are unwieldy, expensive, time-consuming to use, and constantly break down [6].

In fact, when smart phones and tablet landed on the hand of teachers and students and a number of website offers on-line education at no cost, there was an assumption that adopting to it will take a leapfrog. However when Edx was launched even Harvard faculty argued on its impact to its current system [7]. Moreover, since technology gadgets can influence the socio emotions of students, balancing and controlling the use of it are needed [8]. This is one of the evidences of human's resistance to adopt to changes. An illustration that even technological advances offers a modern way on how to do things there are barriers for its implementation.

Since financial investment is at stake in implementing mobile learning, identifying variables on user adoption to it is deemed necessary. This study gives light on which factors to address and the challenges administrators are facing in enhancing teaching and learning through technology. When all these where identified and considered, adoption will no longer an issue if in the future new technology for improvement and sustainability are introduced.

\section{Background of the Study}

Currently, Centro Escolar University is considering a new learning management system (LMS) as an enhancement to its various learning modalities for its diverse learners that can be accessed in mobile. In the context of this study, mobile learning includes the use of LMS in mobile devices. Since both technologies offers features that when adopted could provide a brand new way to conduct classes as well as in- 
crease teachers' productivity and enrich classroom experiences to the students, this study was conducted. This study determined the adoption of mobile learning using Unified Theory of Acceptance and Use of Technology (UTAUT). Using this model, it could determine teachers' and students' attitude, preparedness and concerns with regard to mobile learning adoption [9].

\section{Statement of the Problem}

1. What is the profile of the respondents in terms of:
(a) age;
(b) gender;
(c) experience;
(d) voluntariness of use and
(e) mobile devices ownership?

2. How do the respondents assess mobile learning based on the following determinants of user intention?

(a) Performance Expectancy (PE);

(b) Effort Expectancy (EE);

(c) Social Influence (SI);

(d) Facilitating Conditions (FC);

(e) Anxiety(AX) ;

(f) Self-Efficacy(SE);

3. How do the respondents assessments of mobile learning in terms of performance expectancy, effort expectancy, social influence and facilitating conditions compare when grouped according to age, gender, voluntariness of use and experience?

4. Among the determinants of behavioral intention, which are the factors that will make the teachers and students adopt mobile learning?

\section{$4 \quad$ Hypothesis}

The factors that will make the teachers and students adopt mobile learning will not be determined by the use of UTAUT.

\section{$5 \quad$ Methods and Procedures}

The Sloven's Formula was used to identify the number of respondents needed in this study. The questionnaire was composed of two parts. The first part is for demographic profiling that served as moderating variables which includes the age, gender, voluntariness of use and experience. Part II is patterned to the UTAUT model that made use of determinants of behavioral intention namely performance expectancy, effort expectancy, social influence, facilitating conditions anxiety and self-efficacy. A marked of .957 or excellent verbal interpretation when the questionnaire was checked for internal consistency using Chronbach's Alpha. 461 questionnaires were distributed 
among the students and employees in CEU. These were tested and treated using Statistical Packages for Social Sciences (SPSS) application. The following statistical method, frequency distribution, percentage, mean, standard deviation, T-test, Analysis of Variance (ANOVA) to come up with the needed answers to the question posted.

\subsection{Theoretical framework}

This study is anchored at The Unified Theory of Adoption and Use of Technology. This theory explores the different factors that make adoption to the technology a success. UTAUT is consists of moderating variables such as age, gender, experience and voluntariness of use. These variables when relate to dependent variables performance expectancy, effort expectancy, social influence and facilitating condition factors on the use and adoption can be identified. These identified factors are useful to make necessary adjustment to ensure success in implementation. In the case of this study, all moderating variables were tested to the different dependent variables and on the additional factors, anxiety, self-efficacy and attitude towards using technology thereby increasing the scope on what to consider.

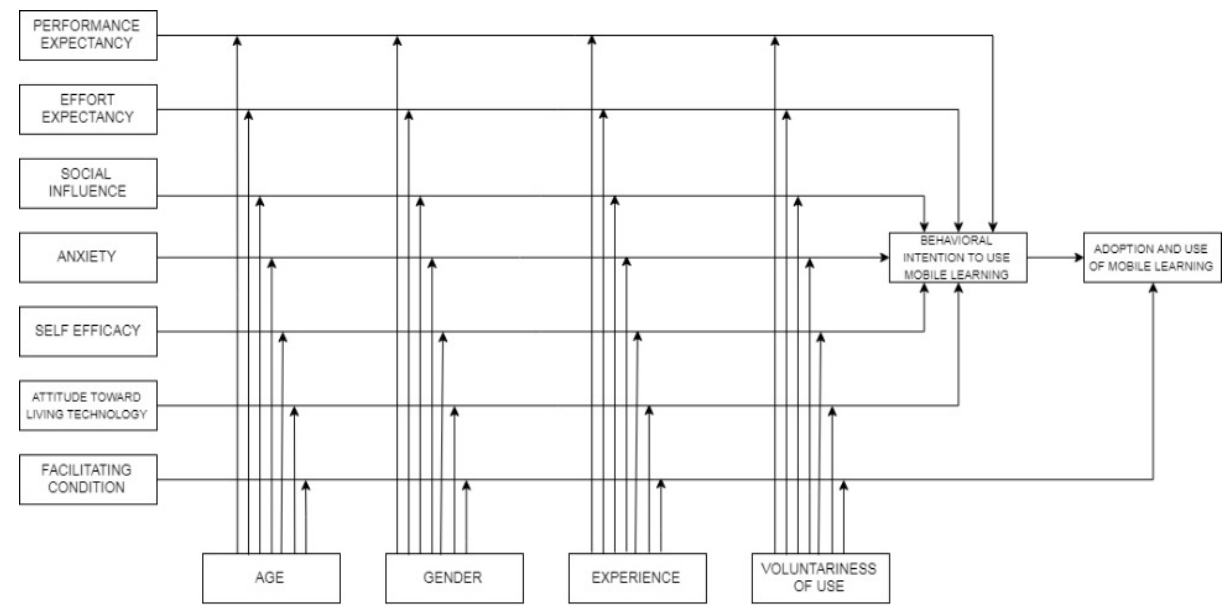

Fig. 1. Modified Unified Theory of Acceptance and Use of Technology (UTAUT)

\subsection{Profile of the respondents}

Out of 461 respondents, majority of it is within the age ranges from 19 to below or $65.9 \%$ percent. The respondents were mostly female or $63.4 \%$, which is in the third year level and consider using mobile in learning as voluntary. A number of respondents answered smartphones as the device they use for mobile learning which is 76.8 percent while tablets and netbooks scored $34.5 \%$ and 9.3 percent respectively. 


\section{$6 \quad$ Results and Discussions}

In assessing the different determinants of user intention a five-point Likert scale was used.

The Assessments of Mobile Learning in terms of Performance Expectancy is presented on table1. The respondents agreed that learning from mobile is useful to his/her work or study $(x=4.25)$. It enables them to accomplish the task quickly $(x=4.18)$, increases productivity $(x=4.13)$, and increases the chance of getting good grades or good performance in their job $(x=4.02)$. The overall mean $(x=4.48)$ strongly suggest that learning from mobile help them attain gain in study/job performance. Performance expectancy has direct effect on the adoption of web based training [10] [11].

To take advantage of the results presented, teachers could use mobile devices in enriching the teaching and learning experience of the students within or outside the campus by creating activities because students will surely take interest on it.

Table 1. Assessments of Mobile Learning in terms of Performance Expectancy

\begin{tabular}{|c|c|c|c|c|}
\hline \multicolumn{5}{|c|}{ Performance Expectancy } \\
\hline & $N$ & Mean & $\begin{array}{l}\text { Std. Devia- } \\
\text { tion }\end{array}$ & $\begin{array}{c}\text { Verbal } \\
\text { Interpretation }\end{array}$ \\
\hline Learning from mobile is useful to my work/study. & 460 & 4.2478 & 1.3331 & Agree \\
\hline $\begin{array}{l}\text { Using mobile devices enables me to accomplish task more } \\
\text { quickly. }\end{array}$ & 460 & 4.1826 & 1.3008 & Agree \\
\hline Learning from mobile increases my productivity. & 458 & 4.1332 & 1.2715 & Agree \\
\hline $\begin{array}{l}\text { Learning from mobile increases my chances of getting a good } \\
\text { grade/good performance rating. }\end{array}$ & 459 & 4.0261 & 1.2466 & Agree \\
\hline Performance Expectancy & 461 & 4.478 & 1.2094 & Agree \\
\hline
\end{tabular}

As seen on Table 2, on the Assessments of Mobile Learning In Terms of Effort Expectancy. The result on effort expectancy connotes that both students and faculty do not have a hard time to use mobile devices in teaching and learning. The overall mean $(X=3.65)$ suggests that respondents exerted less effort to use the system to achieve his/her goals in using mobile to learn/teach. Based on the rating, respondent's claimed that it is easier for them to use mobile in the learning/teaching $(\mathrm{x}=3.59)$ as well as to become skillful $(\mathrm{x}=3.87)$. On the other hand, the rating on the use of mobile devices $(x=3.62)$ and connecting to internet $(x=3.51)$ using their gadgets were easy for them as noted on the results. Effort expectancy confirms that when a technology is easy to use and require less effort is one of the reasons why user adopts a system [12].

Social Influence as defined by Venkatesh is the degree to which an individual perceives that people who are important to him/her believe that he/she should use the new technology which the overall mean of $(x=3.92)$ implies as reflected on table 3.

People who influence respondent's behavior $(x=3.87)$ and those that are important to them $(x=3.82)$ think that they should teach/learn through mobile. The support to use mobile devices is also seen in their classmates and colleagues, in fact respondents claimed they have been helpful in the use mobile in the teaching/learning $(x=3.92)$. However, the results minimally agree was yielded when the respondents were ask on 
the university's support on the use of mobile in teaching/learning $(x=3.09)$. On the interview with the respondents in investigating on why the aforementioned results were derived, the policy on mobile use inside the classroom as well as the low wi-fi signal in the campus are the two common reasons. People adopt technology to blend or connect to other people [13]. However, after the user used the technology social influence is no longer significant [14].

Table 2. Assessments of Mobile Learning In Terms of Effort Expectancy

\begin{tabular}{|c|c|c|c|c|}
\hline \multicolumn{5}{|l|}{ Effort Expectancy } \\
\hline & $N$ & Mean & $\begin{array}{c}\text { Std. } \\
\text { Deviation }\end{array}$ & $\begin{array}{c}\text { Verbal } \\
\text { Interpretation }\end{array}$ \\
\hline Using mobile to learn/teach is easy for me. & 461 & 3.5900 & 1.19920 & Agree \\
\hline $\begin{array}{l}\text { It is easy for me to become skillful through mobile } \\
\text { learning/teaching }\end{array}$ & 461 & 3.8698 & 1.12113 & Agree \\
\hline Mobile devices in teaching/learning is easy for me. & 461 & 3.6291 & 1.20467 & Agree \\
\hline $\begin{array}{l}\text { Connecting to internet for mobile learning is easy } \\
\text { for me. }\end{array}$ & 460 & 3.5087 & 1.20182 & Agree \\
\hline Effort Expectancy & 461 & 3.6497 & 1.05943 & Agree \\
\hline
\end{tabular}

Table 3. Assessments of Mobile Learning in terms of Social Influence

\begin{tabular}{|c|c|c|c|c|}
\hline \multicolumn{5}{|l|}{ Social Influence } \\
\hline & $N$ & Mean & \begin{tabular}{c|} 
Std. \\
Deviation
\end{tabular} & $\begin{array}{c}\text { Verbal } \\
\text { Interpretation }\end{array}$ \\
\hline $\begin{array}{l}\text { People who influence my behavior think that I should teach/learn } \\
\text { through mobile }\end{array}$ & 461 & 3.8655 & 1.07102 & Agree \\
\hline $\begin{array}{l}\text { People who are important to me think that I should use mobile } \\
\text { devices in teaching/learning }\end{array}$ & 461 & 3.8265 & 1.09358 & Agree \\
\hline $\begin{array}{l}\text { My classmates/colleagues have been helpful in the use mobile in } \\
\text { teaching/learning }\end{array}$ & 460 & 3.9174 & 1.15363 & Agree \\
\hline $\begin{array}{l}\text { In general, the university has supported the use of mobile in learn- } \\
\text { ing. }\end{array}$ & 461 & 3.0954 & 1.18119 & $\begin{array}{l}\text { Minimally } \\
\text { Agree }\end{array}$ \\
\hline Social Influence & 461 & 3.9262 & .99850 & Agree \\
\hline
\end{tabular}

On facilitating condition as seen on table 4 , the overall mean score of 4.14 shows the respondents' belief that an organizational and technical infrastructure exists to support the use of mobile in the teaching and learning. The ratings on the table reflected that availability of resources exists in CEU $(x=4.23)$ and respondents have the necessary knowledge $(x=4.34)$ to use mobile devices in teaching and learning. The respondents also agreed that their mobile device is always compatible with other systems they use $(x=3.95)$ and in case they need assistance there is a specific person or group is available $(x=4.04)$. Financing, skills, capacity and infrastructure are examples of challenges encountered when implementing technologies [15].

In the case of CEU, the Teaching and Learning Technology Department (TLTD) and Information Communication Technology (ICT) are the departments responsible in 
facilitating the use of modern technology. The former is responsible in implementing technological advances in the teaching and learning process while the latter is on implementing such infrastructure needed to modernize CEU.

Table 4. Assessments of Mobile Learning in terms of Facilitating Condition

\begin{tabular}{|c|c|c|c|c|}
\hline \multicolumn{5}{|l|}{ Facilitating Condition } \\
\hline & $N$ & Mean & \begin{tabular}{c|} 
Std. \\
Deviation
\end{tabular} & $\begin{array}{c}\text { Verbal } \\
\text { Interpretation }\end{array}$ \\
\hline I have the resources necessary to learn from mobile & 461 & 4.2321 & 1.13842 & Agree \\
\hline I have the knowledge necessary to use mobile in learning & 460 & 4.3413 & 1.12354 & Agree \\
\hline $\begin{array}{l}\text { My mobile device used in learning is always compatible with other } \\
\text { systems I use. }\end{array}$ & 460 & 3.9565 & 1.18370 & Agree \\
\hline $\begin{array}{l}\text { A specific person (or group) is available for assistance with my } \\
\text { mobile device }\end{array}$ & 459 & 4.0414 & 1.15805 & Agree \\
\hline Facilitating Condition & 461 & 4.1421 & .98192 & Agree \\
\hline
\end{tabular}

Anxiety and Self efficacy are the additional variables tested in this study, this test that aside from perceived usefulness other factors are being considered by users before adapting to new technology [16]. Anxiety questions measure the degree of an individual apprehension or even fear when he/she is faced with the possibility of using mobile devices in teaching and learning is reflected on table 5. All indicators of anxiety level were rated minimially agree, from respondents apprehension $(x=2.91)$, security issues $(x=2.76)$, fear of making mistakes $(x=2.59)$, down to the feeling of being intimidated $(x=2.61)$. The overall rating of $(x=2.72)$ suggests that anxiety in using mobile devices is not a matter to consider when in using mobile in the teaching and learning.

Table 5. Assessments of Mobile Learning in terms of Anxiety

\begin{tabular}{|c|c|c|c|c|}
\hline \multicolumn{5}{|c|}{ Anxiety } \\
\hline & $N$ & Mean & $\begin{array}{c}\text { Std. } \\
\text { Deviation }\end{array}$ & $\begin{array}{c}\text { Verbal } \\
\text { Interpretation }\end{array}$ \\
\hline I feel apprehensive about using mobile in learning & 459 & 2.9107 & 1.07303 & Minimally Agree \\
\hline It scares me to think that mobile learning is not safe & 460 & 2.7630 & 1.09780 & Minimally Agree \\
\hline $\begin{array}{l}\text { I hesitate to use mobile in learning of fear of making } \\
\text { mistakes I cannot correct. }\end{array}$ & 458 & 2.5939 & 1.09750 & Minimally Agree \\
\hline Mobile learning is somewhat intimidating to me. & 459 & 2.6144 & 1.08054 & Minimally Agree \\
\hline Anxiety & 461 & 2.7178 & .96465 & Minimally Agree \\
\hline
\end{tabular}

Table 6 shows the result on self-efficacy of the respondents. Self-efficacy refers to an individual's belief in his or her capacity to execute behaviors necessary to produce specific performance attainments [17]. The capacity of the respondents to use mobile in the teaching and learning is high as seen on the different indicators of self-efficacy. This means that respondents believe in their own ability to succeed in accomplishing 
task. Students will use technology when it is capable of increasing their efficiency [18].

The overall rating of 3.29 translated to as minimally agree when ask whether the respondents could perform the task when there is someone around to tell them what to do while working $(x=4.30)$, calling help desk for oral instruction $(x=3.24)$, plenty of time and resources are provided $(x=3.35)$ and instruction readily available $(x=3.26)$ are not necessary for them to complete their job or task.

Table 6. Assessments of Mobile Learning in terms of Self Efficacy

\begin{tabular}{|c|c|c|c|c|}
\hline \multicolumn{5}{|l|}{ Self-Efficacy } \\
\hline & $N$ & Mean & $\begin{array}{c}\text { Std. } \\
\text { Deviation }\end{array}$ & $\begin{array}{l}\text { Verbal } \\
\text { Interpretation }\end{array}$ \\
\hline \multicolumn{5}{|l|}{ I can complete a job or task using mobile: } \\
\hline If there is someone around to tell me what to do as I work. & 461 & 4.3080 & 1.16120 & Minimally Agree \\
\hline If I can call to help desk for oral instruction & 460 & 3.2391 & 1.04130 & Minimally Agree \\
\hline $\begin{array}{l}\text { If I have a lot of time to complete the job and resources are } \\
\text { provided. }\end{array}$ & 461 & 3.3536 & 1.09084 & Minimally Agree \\
\hline If I have the instruction readily available & 461 & 3.2646 & 1.09912 & Minimally Agree \\
\hline Self- Efficacy & 461 & 3.2914 & .98283 & Minimally Agree \\
\hline
\end{tabular}

Table 7 presents the comparison of respondents' assessments of mobile learning technology in terms of performance expectancy, effort expectancy, social influence and facilitating conditions when grouped according to age bracket. Looking at the table age of a person yielded a very significant variable in the results of performance expectancy, effort expectancy, social influence and facilitating conditions when analyzing the adoption of an individual to technology. An F value of .949 with a mark of 001with a verbal interpretation of very significant was observed on pair 19-below VS $30-39$, connotes that in terms of performance expectancy, older respondents tend to adopt the technology more compared to younger respondents. This means that technology will be adopted more by older individuals if this will help them excel in their performance or help them in their task or job compared to younger individuals. Therefore, performance expectancy has positive impact to older individuals when compared to younger individuals on mobile learning.

On the other hand, effort expectancy has positive impact to younger individuals when compared to older individuals. An F value of 9.117 with a mark of .001 with a verbal interpretation of very significant was observed to pairs 19-below VS $20-29$, 19- below VS 30 - 39, 19- below VS 40 -49 and 19- below VS 50-above in terms of effort expectancy. This data connotes that young ones exerted less effort in mobile learning compared to older people.

Influencing younger individuals on the adoption to mobile learning is much easier compared to older individuals. The data prove this because an $\mathrm{F}$ value of 5.823 with a mark of .000 with a verbal interpretation of very significant was observed to pairs 19below VS 20 - 29, 19- below VS 30 - 39, 19- below VS 40 -49 and 19- below VS 50above in terms of social influence. Opinions of the people who are important to them 
are much regard and by young ones compared to older people. Therefore social influence in mobile learning has positive impact to younger compared to older individuals.

When it comes to facilitating condition, there is a positive impact on older individuals on the adoption to mobile learning compared to younger individuals. An $\mathrm{F}$ value of 5.9775 with a mark of .000 with a verbal interpretation of very significant was observed to pairs 19- below VS 30 - 39, 19- below VS 40 -49 and 19- below VS 50above was the basis of this analysis. Older persons have more positive views that organizational and technical infrastructure exist to support mobile learning compared to younger individuals. This shows that older persons are more aware that in the organization there is a unit that will assist them on the use of mobile learning. This difference suggest that adults put emphasis on facilitating condition compared to younger person [19]. Using this finding older people will look for someone to assist them on their technology needs.

An $\mathrm{F}$ value of 2.963 with a mark of .016 and a verbal interpretation of significant was observed to pairs 19 - below VS 50 above, 20 - 29 VS 50 above, 30 - 39 VS 50 above and 40 - 49 VS 50 above yielded from Anxiety. The data connotes that younger individuals exhibit a positive emotional reaction towards mobile learning compared to older persons.

It is safe to say that self-efficacy of the respondents when related to age is not significant in the adoption of mobile learning, an F value of 1.504 with a mark of .200 as seen on table. Understanding age difference is beneficial on the use of technology [20].

Among the determinants of user intention, facilitating condition and self-efficacy were found to have a significant difference when the respondents are grouped according to gender. The scores for facilitating condition in female respondents $(x=3.0234$, $\mathrm{SD}=.98717)$ and male respondents $(\mathrm{x}=3.3159, \mathrm{SD}=.94511)$ with a value of $=3.096$, $\mathrm{p}=.003$ ) suggests that male respondents have higher belief that organizational and technical infrastructure such as hardware, software and people resources exists in CEU for mobile learning compared to female respondents.

In terms of self-efficacy, the results show that female respondents $(x=3.1750$, $\mathrm{SD}=1.02900)$ and male respondents $(\mathrm{x}=3.4835, \mathrm{SD}=.86999)$ with a value of $=3.259$ $\mathrm{p}=.001$ ). Male users' belief in his capacity towards mobile learning is greater when compared to female respondents. This suggests that male users are more independent in doing task related to mobile learning and that male are more users of technology compared to female. This findings relates to that male students has higher selfefficacy in computing than the male students.[21]

However in table 8, there is no significant relationship when respondents' assessments of mobile learning in terms of performance expectancy, effort expectancy, social influence and anxiety when grouped according to gender. 
Table 7. Comparison of Respondents' Assessments of Mobile Learning Technology In Terms Of Performance Expectancy, Effort Expectancy, Social Influence and Facilitating Conditions When Grouped According To Age

\begin{tabular}{|c|c|c|c|c|c|c|c|}
\hline & & Mean & SD & $\mathbf{F}$ & Sig. & V.I. & Pair \\
\hline \multirow{6}{*}{$\begin{array}{l}\text { Performance Expec- } \\
\text { tancy }\end{array}$} & 19 below & 4.01 & 1.19 & \multirow{6}{*}{.949} & \multirow{6}{*}{.001} & \multirow{6}{*}{$\begin{array}{l}\text { Very } \\
\text { Signifi- } \\
\text { cant }\end{array}$} & \multirow{6}{*}{ 19- below VS 30-39 } \\
\hline & $20-29$ & 4.24 & 1.21 & & & & \\
\hline & $30-39$ & 4.80 & 1.05 & & & & \\
\hline & $40-49$ & 4.5 & 1.30 & & & & \\
\hline & 50-above & 4.91 & 1.14 & & & & \\
\hline & Total & 4.14 & 1.22 & & & & \\
\hline \multirow{6}{*}{$\begin{array}{l}\text { Effort } \\
\text { Expectancy }\end{array}$} & 19 below & 3.53 & 0.99 & \multirow{6}{*}{9.117} & \multirow{6}{*}{.001} & \multirow{6}{*}{$\begin{array}{l}\text { Very } \\
\text { Signifi- } \\
\text { cant }\end{array}$} & \multirow{6}{*}{$\begin{array}{l}\text { 19- below VS } 20-29 \\
19 \text { - below VS } 30-39 \\
19 \text { - below VS } 40-49 \\
19-\text { below VS } 50 \text {-above }\end{array}$} \\
\hline & $20-29$ & 3.60 & 1.00 & & & & \\
\hline & $30-39$ & 4.19 & 1.13 & & & & \\
\hline & $40-49$ & 4.39 & 1.48 & & & & \\
\hline & 50-above & 4.84 & 1.16 & & & & \\
\hline & Total & 3.65 & 1.06 & & & & \\
\hline \multirow{6}{*}{$\begin{array}{l}\text { Social } \\
\text { Influence }\end{array}$} & 19 below & 3.83 & 0.98 & \multirow{6}{*}{5.823} & \multirow{6}{*}{.000} & \multirow{6}{*}{$\begin{array}{l}\text { Very } \\
\text { Signifi- } \\
\text { cant }\end{array}$} & \multirow{6}{*}{$\begin{array}{l}\text { 19- below VS } 20 \text { - } 29 \\
19 \text { - below VS } 30-39 \\
19 \text { - blow VS } 40-49 \\
19 \text { - below VS } 50 \text {-above }\end{array}$} \\
\hline & $20-29$ & 3.88 & 0.99 & & & & \\
\hline & $30-39$ & 4.45 & 0.83 & & & & \\
\hline & $40-49$ & 4.39 & 1.07 & & & & \\
\hline & 50-above & 4.75 & 1.18 & & & & \\
\hline & Total & 3.92 & 0.99 & & & & \\
\hline \multirow{6}{*}{$\begin{array}{l}\text { Facilitating } \\
\text { Condition }\end{array}$} & 19 below & 4.02 & 0.95 & \multirow{6}{*}{5.977} & \multirow{6}{*}{.000} & \multirow{6}{*}{$\begin{array}{l}\text { Very } \\
\text { Signifi- } \\
\text { cant }\end{array}$} & \multirow{6}{*}{$\begin{array}{l}\text { 19- below VS } 30 \text { - } 39 \\
19 \text { - below VS } 40-49 \\
19 \text { - below VS } 50 \text {-above }\end{array}$} \\
\hline & $20-29$ & 4.22 & 0.91 & & & & \\
\hline & $30-39$ & 4.54 & 1.04 & & & & \\
\hline & $40-49$ & 4.56 & 1.16 & & & & \\
\hline & 50-above & 4.98 & 1.16 & & & & \\
\hline & Total & 4.14 & 0.98 & & & & \\
\hline \multirow{6}{*}{ Anxiety } & 19 below & 3.7803 & 0.94302 & \multirow{6}{*}{2.963} & \multirow{6}{*}{.016} & \multirow{6}{*}{$\begin{array}{l}\text { Signifi- } \\
\text { cant }\end{array}$} & \multirow{6}{*}{$\begin{array}{l}19 \text { - below VS } 50 \text { above } \\
20 \text { - } 29 \text { VS } 50 \text { above } \\
30 \text { - } 39 \text { VS } 50 \text { above } \\
40 \text { - } 49 \text { VS } 50 \text { above }\end{array}$} \\
\hline & $20-29$ & 3.7323 & 0.94102 & & & & \\
\hline & $30-39$ & 3.5081 & 1.02161 & & & & \\
\hline & $40-49$ & 3.625 & 1.07626 & & & & \\
\hline & 50 above & 2.8409 & 1.10834 & & & & \\
\hline & Total & 3.7178 & 0.96465 & & & & \\
\hline \multirow{6}{*}{ Self-Efficacy } & 19 below & 3.2281 & 0.9947 & \multirow{6}{*}{1.504} & & & \\
\hline & $20-29$ & 3.4066 & 0.91584 & & & & \\
\hline & $30-39$ & 3.5806 & 0.86936 & & 200 & Not & \\
\hline & $40-49$ & 3.375 & 1.03682 & & .200 & $\begin{array}{l}\text { S1gnit1- } \\
\text { cant }\end{array}$ & \\
\hline & 50 above & 3.0682 & 1.33272 & & & & \\
\hline & Total & 3.2914 & 0.98283 & & & & \\
\hline
\end{tabular}


Table 8. Comparison of the Determinants of User Intention When grouped according to Gender

\begin{tabular}{|c|c|c|c|c|c|}
\hline \multicolumn{6}{|c|}{ Group Statistics } \\
\hline & Gender & Mean & Std. Deviation & t value & $\begin{array}{c}\text { Verbal } \\
\text { Interpretation }\end{array}$ \\
\hline \multirow{2}{*}{ Performance Expectancy } & Male & 3.1921 & 1.24308 & \multirow{2}{*}{$.759 p=.448$} & \multirow{2}{*}{ Not Significant } \\
\hline & Female & 3.1024 & 1.19989 & & \\
\hline \multirow{2}{*}{ Effort Expectancy } & Male & 2.7605 & 1.13387 & \multirow{2}{*}{$1.842 \mathrm{p}=.066$} & \multirow{2}{*}{ Not Significant } \\
\hline & Female & 2.5718 & 1.00489 & & \\
\hline \multirow{2}{*}{ Social Influence } & Male & 2.9686 & 1.02718 & \multirow{2}{*}{$.815 \mathrm{p}=.415$} & \multirow{2}{*}{ Not Significant } \\
\hline & Female & 2.8893 & .98506 & & \\
\hline \multirow{2}{*}{ Facilitating Condition } & Male & 3.3159 & .94511 & \multirow{2}{*}{$3.096 \mathrm{p}=.003$} & \multirow{2}{*}{ Very Significant } \\
\hline & Female & 3.0234 & .98717 & & \\
\hline \multirow{2}{*}{ Anxiety } & Male & 2.8009 & 1.01366 & \multirow{2}{*}{$1.480 \mathrm{p}=.139$} & \multirow{2}{*}{ Not Significant } \\
\hline & Female & 2.6623 & .93250 & & \\
\hline \multirow{2}{*}{ Self -Efficacy } & Male & 3.4835 & .86999 & \multirow{2}{*}{$3.259 \mathrm{p}=.001$} & \multirow{2}{*}{ Very Significant } \\
\hline & Female & 3.1750 & 1.02900 & & \\
\hline
\end{tabular}

Table 9 presents the results on the comparison of the respondents' assessments of mobile learning in terms of performance expectancy, effort expectancy, social influence and facilitating conditions when grouped according to experience. Among the determinants of user behavior, experience when related to self-efficacy has no significance. This was based on the yielded data $1^{\text {st }}$ Year $(x=3.30, S D=0.86), 2^{\text {nd }}$ Year $(x=3.54, S D=0.99), 3^{\text {rd }}$ Year $(x=3.17, S D=1.037), 4$ th $Y$ ear $(x=3.47, S D=1.093)$ and Employee $(\mathrm{x}=3.48, \mathrm{SD}=0.98)$ with a value of $=1.601 \mathrm{p}=.158)$.

Significant findings were found between pair $1^{\text {st }}$ Years and faculty On the assessment on performance expectancy, the mark of $1^{\text {st }}$ Year $(\mathrm{x}=3.05, \mathrm{SD}=1.11)$ and faculty $(\mathrm{x}=3.95, \mathrm{SD}=1.19)$ suggests that employees adoption to mobile learning is higher because they believe that this will help them in their work compared to students' rating. The same findings are on effort expectancy $1^{\text {st }}$ Year $(x=2.55, S D=0.94)$ vs Faculty $(\mathrm{x}=3.51, \mathrm{SD}=1.00)$, social influence $1^{\text {st }}$ Year $(\mathrm{x}=2.88, \mathrm{SD}=0.97)$ vs Faculty $(\mathrm{x}=3.43, \mathrm{SD}=1.06)$ and anxiety $1^{\text {st }}$ Year $(\mathrm{x}=2.87, \mathrm{SD}=0.90)$ vs Faculty $(\mathrm{x}=2.13$, $\mathrm{SD}=0.98$ ). These data suggest that there is a higher tendency for the faculty compared to $1^{\text {st }}$ Year students to adopt mobile learning if the use of such technology is easy and effortless, influenced by their peers to use and a worry free adoption.

Table 9. Comparison Of The Respondents' Assessments Of Mobile learning In Terms Of Performance Expectancy, Effort Expectancy, Social Influence And Facilitating Conditions When Grouped According To Experience

\begin{tabular}{|c|c|c|c|c|c|c|c|}
\hline & & Mean & SD & $\mathbf{F}$ & Sig. & V.I. & Pair \\
\hline \multirow{4}{*}{ Performance Expectancy } & $1^{\text {st }}$ Year & 3.0525 & 1.11944 & \multirow{4}{*}{3.294} & \multirow{4}{*}{.011} & \multirow{4}{*}{ Very Significant } & \multirow{4}{*}{1 VS 5} \\
\hline & $2^{\text {nd }}$ Year & 3.4645 & 1.24428 & & & & \\
\hline & $3^{\text {rd }}$ Year & 3.0127 & 1.20667 & & & & \\
\hline & $4^{\text {th }}$ Year & 2.9265 & 1.31626 & & & & \\
\hline
\end{tabular}




\begin{tabular}{|c|c|c|c|c|c|c|c|}
\hline & Employee & 3.9464 & 1.13162 & & & & \\
\hline & Total & 3.1085 & 1.19753 & & & & \\
\hline \multirow{6}{*}{ Effort Expectancy } & $1^{\text {st }}$ Year & 2.5543 & .94596 & \multirow{6}{*}{4.152} & \multirow{6}{*}{.003} & \multirow{6}{*}{ Very Significant } & \multirow{6}{*}{1 VS 5} \\
\hline & $2^{\text {nd }} Y$ ear & 2.6968 & 1.01341 & & & & \\
\hline & $3^{\text {rd }}$ Year & 2.4552 & .98122 & & & & \\
\hline & $4^{\text {th }}$ Year & 2.7500 & 1.12152 & & & & \\
\hline & Employee & 3.5179 & 1.31728 & & & & \\
\hline & Total & 2.5675 & 1.00756 & & & & \\
\hline \multirow{6}{*}{ Social Influence } & $1^{\text {st }}$ Year & 2.8804 & .97094 & \multirow{6}{*}{2.564} & \multirow{6}{*}{.038} & \multirow{6}{*}{ Significant } & \multirow{6}{*}{$1 \mathrm{VS} 5$} \\
\hline & $2^{\text {nd }}$ Year & 3.1330 & .95104 & & & & \\
\hline & $3^{\text {rd }}$ Year & 2.7690 & .94394 & & & & \\
\hline & $4^{\text {th }}$ Year & 2.9265 & 1.07079 & & & & \\
\hline & Employee & 3.4286 & 1.0620 & & & & \\
\hline & Total & 2.8800 & .97122 & & & & \\
\hline \multirow{6}{*}{ Anxiety } & $1^{\text {st }}$ Year & 2.87 & 0.90 & \multirow{6}{*}{4.927} & \multirow{6}{*}{.000} & \multirow{6}{*}{ Very Significant } & \multirow{6}{*}{$1 \mathrm{VS} 52 \mathrm{VS} 5$} \\
\hline & $2^{\text {nd }}$ Year & 3.03 & 1.00 & & & & \\
\hline & $3^{\text {rd }}$ Year & 2.69 & 0.93 & & & & \\
\hline & $4^{\text {th }}$ Year & 2.41 & 0.78 & & & & \\
\hline & Employee & 2.13 & 0.98 & & & & \\
\hline & Total & 2.72 & 0.95 & & & & \\
\hline \multirow{6}{*}{ Self-Efficacy } & $1^{\text {st }}$ Year & 3.30 & 0.86 & \multirow{6}{*}{1.601} & \multirow{6}{*}{.158} & \multirow{6}{*}{ Not Significant } & \\
\hline & $2^{\text {nd }}$ Year & 3.54 & 0.99 & & & & \\
\hline & $3^{\text {rd }}$ Year & 3.17 & 1.037 & & & & \\
\hline & $4^{\text {th }}$ Year & 3.47 & 1.093 & & & & \\
\hline & Employee & 3.48 & 1.096 & & & & \\
\hline & Total & 3.29 & 0.98 & & & & \\
\hline
\end{tabular}

Comparison Of The Respondents' Assessments Of Mobile Learning In Terms Of Performance Expectancy, Effort Expectancy, Social Influence And Facilitating Conditions When Grouped According To Voluntariness Of Use. In terms of respondents' assessments of WI-FI technology when grouped according to voluntariness of use compared with the different determinants of user intention no significant finding were yielded. Free will is not a factor to consider in adopting mobile learning.

Table 10. Predictor of the User Intention to adopt mobile learning

\begin{tabular}{|l|c|c|}
\hline \multicolumn{1}{|c|}{ Determinants } & $\begin{array}{c}\text { R square } \\
\text { (Coefficient of Determination) }\end{array}$ & $\begin{array}{c}\boldsymbol{\beta} \\
\text { (Beta Coefficient) }\end{array}$ \\
\hline Facilitating Condition & $36 \%$ & \\
\hline Performance Expectancy & $44 \%$ & \\
\hline Effort Expectancy & $48 \%$ & \\
\hline Self-Efficacy & $51 \%$ & \\
\hline Anxiety & $53 \%$ & \\
\hline
\end{tabular}

Excluded
\begin{tabular}{|l|c|c|}
\hline \multicolumn{1}{|c|}{ Determinants } & $\begin{array}{c}\text { R square } \\
\text { (Coefficient of Determination) }\end{array}$ & $\begin{array}{c}\boldsymbol{\beta} \\
\text { (Beta Coefficient) }\end{array}$ \\
\hline Social Influence & & \\
\hline
\end{tabular}


Between determinants of user to adopt mobile learning, anxiety top the rank (53\%), followed by self-efficacy (51\%), effort expectancy (48\%), performance expectancy (44\%) and facilitating condition (36\%) as the last factor. Excluded from the factor is social influence. This explains that among the determinants of user intention respondents' anxiety is a good predictor in adopting mobile learning while influences from their peers will not contribute its success.

\section{Conclusion}

Anxiety, self-efficacy and effort expectancy are the top three identified factors in the use and adoption of mobile learning using UTAUT model. There is a need to mitigate faculty and students findings of apprehension, fear, hesitation and intimidation. Increase the confidence of the faculty and students by providing training workshops and demonstration on the use of mobile learning is necessary. A comprehensive program to implement to develop skills needed in shifting on the use of technology in the teaching and learning process. Since self-efficacy was also identified as one of the factors inclusion of criteria in their performance ranking and on grading system on mobile learning can be a scheme to make adoption a success. Moreover recognizing the effort on the use of technology could also be a strategy. Hence forth in the future anxiety, self-efficacy and effort expectancy will no longer be a factor why adopting to new technology will fail.

\section{$8 \quad$ Recommendation}

As an initial action to address anxiety on the adoption to mobile learning, training of users, provision of technical assistance to faculty and students and readily available manuals and guidelines should be drafted to ensure success in mobile learning implementation.

\section{$9 \quad$ References}

[1] Boren, Z. D. (2014, October 7). Independent. Retrieved from Indendent: more-mobiledevices-than-people-in-the-world-9780518.html

[2] Nordrum, A. (2016, August 18). IEEE Spectrum. Retrieved December 13, 2017, from IEEE Spectrum: https://spectrum.iee.org/tech-talk/telecom/internet/popular-internet-of-thi ngs-forecast-of-50-billion-devices-by-2020-is-outdated. https://doi.org/10.1109/mspec.201 6.7572524 .

[3] Statistica. (2016). The Statistical Portal. Retrieved Deceber 13, 2017, from Statistica: https://www.statista.com/statistics/268232/top-10-countries-by-number-of-mobile-cellularsubscriptions/

[4] Gutierrez, K. (2016, December 1). Shift-Disruptive E-Learning. Retrieved from ShiftDisruptive E learning: https://www.shiftelearning.com/blog/bid/331987/mobile- learningstats- that-will-make-you-rethink-your-training-strategy 
[5] Hsiung, W. Y. (2018). The Use of E-Resources and Innovative Technology in Transforming Traditional Teaching in Chemistry and its Impact on Learning Chemistry. International Journal of Interactive Mobile Technologies, 86-96. https://doi.org/10.3991/ ijim.v12i7.9666

[6] Joma, C. (2016, 7 6). World Economic Forum. Retrieved from World Economic Forum: https://www.weforum.org/agenda/2016/07/why-do-people-resist-new-technologies-history -has-answer/

[7] Wu, R. J. (2012, 12 12). The Harvard Crimson . Retrieved from The Harvard Crimson : http://www.thecrimson.com/article/2012/12/12/faculty-edx-courses- debate/?page=1

[8] Zakiah Mohamad Ashari, A. A. (2018). The Relationship between Knowledge and Attitude towards Technology Gadget Usage with Students' Socio-Emotions Development. International Journal of Interactive Mobile Technologies, 152-63. https://doi.org/10.3991/ ijim.v12i7.9711

[9] Viswanath Venkatesh, Michael G. Morris, Gordon B. Davis and Fred D. Davis. MIS Quarterly Vol. 27, No. 3 (Sep., 2003), pp. 425-478

[10] Alrawashdeh, Thamer \& Muhairat, Mohammad \& Qatawneh, Sokyna. (2012). Factors affecting acceptance of web-based training system: Using extended UTAUT and structural equation modeling. https://doi.org/10.5121/ijcseit.2012.2205

[11] Riquelme H, Rios RE (2010). The moderating effect of gender in the adoption of mobile banking. International Journal of Bank Marketing 28: 362-380. https://doi.org/10.1108/026 52321011064872

[12] Sripalawat J, Thongmak M, Ngramyarn A (2011) M-banking in metropolitan Bangkok and a comparison with other countries. The Journal of Computer Information Systems 51: 6776.

[13] Pederson P, Ling R (2002) Modifying adoption research for mobile internet service adoption: cross-disciplinary interactions. In proceedings of the 36th Hawaii International Conference on System Sciences, Big Island, HI. https://doi.org/10.1109/hicss.2003.117421 $\underline{7}$

[14] Hao, Haijing \& Padman, Rema \& Sun, Baohong \& Telang, Rahul. (2014). Examining the Social Influence on Information Technology Sustained Use in a Community Health System: A Hierarchical Bayesian Learning Method Analysis. Proceedings of the Annual Hawaii International Conference on System Sciences. 2751-2758. https://doi.org/10.1109/h icss.2014.345

[15] Kasse, John Paul \& Moya, Musa \& Nansubuga, Annette. (2015). Facilitating Condition for E-learning Adoption-Case of Ugandan Universities. Journal of Communication and Computer. 12. https://doi.org/10.17265/1548-7709/2015.05.004

[16] Satwinderjit Singh, I. A. (2018). New Wave in Mobile Commerce Adoption via Mobile Applications in Malaysian Market: Investigating the Relationship Between Consumer Acceptance, Trust, and Self Efficacy. International Journal of Interactive Mobile Technologies, 152-163. https://doi.org/10.3991/ijim.v12i7.8964

[17] Bandura, A. (1997). Self-Efficacy: The exercise of control. New York, NY: W. H. Freeman.

[18] Ali Tarhini, Mazen El-Masri, Maged Ali, Alan Serrano, (2016) "Extending the UTAUT model to understand the customers' acceptance and use of internet banking in Lebanon: A structural equation modeling approach", Information Technology \& People, Vol. 29 Issue: 4, pp.830-849, https://doi.org/10.1108/ITP-02-2014-0034.

[19] Isa SM, Wong KW “Age Differences in Behavioral Intention to

[20] Use Internet Marketing: A Comparative Study Between Malaysian And Taiwanese".International Journal of Business and Society, Vol. 16 No. 3, 2015, 386 - 396 
[21] W.A. Rogers, T.L. Mitzner, W.R. Boot, N.H. Charness, S.J. Czaja, J. Sharit, Understanding Individual And Age-Related Differences In Technology Adoption, Innovation in Aging, Volume 1, Issue suppl_1, July 2017, Page 1026, https://doi.org/10.1093/geroni/igx004 .3733 .

[22] Marann Byrne, Barbara Flood, Julie Griffin. (2014) Measuring the Academic Self-Efficacy of First-year Accounting Students. Accounting Education 23:5, pages 407-423. https://doi. org/10.1080/09639284.2014.931240

\section{Authors}

Dr. Eliza B. Ayo, PhD, Marcial L. Anacio, Dr. Lani E. Sakay, PhD, Dr. Rosemarievic A. Bustamante, $\mathrm{PhD}$, Dr. Teresita S. Mijares, $\mathrm{PhD}$ are with Centro Escolar University at Manila, Philippines.

Article submitted 2019-05-06. Resubmitted 2019-06-17. Final acceptance 2019-06-18. Final version published as submitted by the authors. 